\title{
The Impact of Biblio group Counseling Supported with the Story of the Little Prince upon Mindfulness
}

\author{
Azmi Bayram İlbay \\ Correspondence: Bulent Ecevit University, Education Faculty, Zonguldak, Eregli, Turkey \\ Received: February 24, 2016 Accepted: March 14, 2016 Online Published: March 22, 2016 \\ doi:10.11114/jets.v4i6.1404 \\ URL: http://dx.doi.org/10.11114/jets.v4i6.1404
}

\begin{abstract}
Using books for healing psychological health is becoming popular day by day. In this process bibliotherapy brings forward suggestions of psychological insight, relieving by identification, relieving from suppressed feelings by discharging and reflecting emotions. The aim of this research is to analyse the effect of biblio group counseling supported by the story of The Little Prince on mindfulness. In this research bibliotherapeutic support was given with 6 session biblio group counseling supported with the metophoric story of The Little Prince.

The pattern of the present research is an experimental study analysing the impact of Biblio Group Counseling Supported with The Story of The Little Prince on the levels of mindfulness. The independent variable of the study is Biblio Group Counseling Supported with the Story of The Little Prince; the dependent variable is the students' mindfulness levels obtained from the scores of Mindful Attention Awareness Scale (MAAS). The pattern of the research is $2 \times 3$ split-plot pattern. Data collecting tools utilized in this research are; personal information form MAAS. When a general inference was made with regard to the findings of this research, it can be stated that Biblio Group Counseling Supported with the Story of The Little Prince enhanced mindfulness levels of individuals in experimental group. This rise was persistent, and stemmed from the effect of empirical practice. Thus sub- hypotheses were confirmed. In conclusion, it was found out that Biblio Group Counseling Supported with the Story of The Little Prince was influential in rising mindfulness levels.
\end{abstract}

Keywords: bibliotherapy, biblio group counseling, the little prince

\section{Introduction}

At the present time using books for healing psychological health is becoming popular (Jones, 2006). Bibliotherapy is defined as the process of producing solutions for emotional problems through reading (McCulliss, 2012; Pardeck \& Pardeck, 1993). According to Yeşilyaprak (2009) bibliotherapy is the process of getting well by means of reading, for Marlowe and Maycook (2000) it is the process of changing behavior through reading, and for Oner (2007) it's treatment with information. McKendree-Smith, Floyd, Scogin (2003) and Pardeck, Pardeck (1984) think bibliotherapy, which contributes individual to actualise himself or herself, is an effective method of problem solving and preventive guidance practices.

In some studies (Bowman, Scogin, \& Lyrene, 1995; Ackerson, Scogin, Mc Kendree-Smith \& Lyman, 1998; Tolin, 2001; Landerville, Landry, Baillargeon, Guerette, \& Matteau, 2001; Prater, Dyches, \& Johnston, 2006; Jones, 2006) it's emphasized that bibliotherapy process could carry developmental and clinical targets. The process transforms into insight acquisition (Janavičienè, 2010). Bibliotherapy is a method that contributes individual's improvement, changing process and healing psychologically (Gladding \& Gladding, 1991; Campbell \& Smith, 2003). Utilizing books in the process of psychological counseling is called bibliocounseling, and if books are utilized in guidance services it's called biblioguidance (Gladding \& Gladding, 1991). Bibliotherapy could produce solutions for individual's emotional and behavioral problems in the process of counseling (Turner, 2008).

In psychological counseling process operation starts with reading the book and continues with talking about its transformative effects (Bulut, 2010b; Oner, 2007). As this process is executed in a psychological counseling group, it develops mindfulness towards the fact that the fact could have different meanings (Ivey, Ivey, \& Downing, 1987). Downing (2007) emphasizes that achievements could become true with individuals or within small counseling groups in psychological counseling practices.

Actualising the stages of identification-reflection, refinement-insight and integration by means of professionals, 
supports its curative and developer qualifications. The first two stages could change in accordance with the problem of the counselee and the dynamics of the counselor (Laquinta \& Hipsky, 2006; Jones, 2006; Oner, 2007; McCulliss, 2012). According to Campbell and Smith (2003) individual develops cognitive awareness in the stage of developing insight in bibliotherapy. Individual gets the opportunity of finding a role model for relieving from emotional distress, developing skill of insight and problem solving as individual focuses on problems at fictional dimension; in fact, he/she executes problem solving ways together with the protogonist. This provides with the opportunity of overcoming resistence which is one of the obstacles within recovery process in psychoterapheutic relationship. In the last stage, as a result of emotional relief, integration of insight and mindfullness comes true. Counselor need to pursue sessions together with bibliotherapy (Williams \& Martines, 2008). These sessions could be done with the aim of monitoring and preventing (Gregory, Canning, Lee, \& Wise, 2004).

Aggressive behavior decreases whereas empathy and insight levels increase in psychological counseling with group taking bibliotherapy support (McCarthy \& Chalmers, 1997). Prater, Dyches and Johnston (2006) state that bibliotherapy could be utilized in developing mindfulness, understanding and compliance. Bibliotherapy could provide the individual who is performing risky behaviors with preventive contributions through self-support (McKendree-Smith, Floyd \& Scogin, 2003). It also bears the quality of being a supportive method for other therapies (Landereville, Landry, Baillergeon, Guerette, \& Matteau, 2001; Campbell \& Smith, 2003).

In the present study bibliotherapeutic support is presented with the story of The Little Prince. The stages of biblio group counseling are based on the story of The Little Prince. In the process of individual's self-knowledge and self-imrovement, tendency of actualising by itself is out of question. Advisors providing with insight and mindfulness, psychological counseling methods and techniques are also necessary in biblio group counseling. The Little Prince is a kind of metaphoric story. Metaphoric qualified works have the privilege of giving the message of changing to readers of all ages. Van Parys and Rober, 2013; Robert and Kelly, 2010 lay emphasis upon utilizing metaphors for providing with psychological support. Metaphors have the quality of forming creative, empathic, open-ended and interactive processes (Karairmak, 2013). The aim of psychological counseling process is mindfulness (Mills \& Crowley, 1986). Besides, this process encourages the feeling of confidence, gives opportunity to surpass resistance and contribute individual's actualising himself/herself by giving chance of changing (Lakoff \& Johnson, 2003). The Little Prince deals with the effort of enriching life with qualifications belonging to chidhood versus the pressure of adult's selfish world which is narrowed, monotonic and full of vicious cycle. Variety of thought, sensitivity, ability to dream, belief for trying new things, unconditioned love, amity, enthusiastic feelings, boundless happiness potential, which are not found in adults, are privileges of childish richness. The adults who haven't lost their childhood and carry the colors of the child world are the ones that deserve respect. The Little Prince opens the way for satisfying curiousity about what the confrontation of richness of being a child and adulthood would make an individual live through. The Little Prince, who presents the richness of being a child, could probably come to the help of the adults who are isolated, battered, deprived of strength and suppressing their childish sides.

Dependent variable of the study is mindfulness which comes out in association with insight aquisitions within biblio group counseling processes. Mindfulness could be taken into consideration as a psychological process (Germer, Siegel \& Fulton, 2005; Ogurlu \& Sarıcam, 2015). Mindfulness is the steering of attention. It is the practice of mind and body directed to instant living and experience (Kabat Zinn, 2009). It is being aware without judging the moment (Stahl \& Goldstein, 2010). It is the state of paying attention to and being aware of the thing happening at the moment. It involves awareness and attention. It's the state of clarity, acquiescent awareness and being careful. (Westen, 1999; Brown \& Ryan, 2003). It's the privilege of conscious living obtained from questioning life. It is self-monitoring, questioning and being careful (Kabat-Zinn, 1994). It is the ability of living the moment in full function. It's heading for life in a submissive manner. (Germer, 2005). Being conscious of thinking, and allowing thought and feelings to reveal freely could diminish individual's sorrow (Gilbert, 2005). This impact is one of the contributions provided by mindfulness. Mindfulness is consciousness, purposefulness, flexibility, clarity, creativeness and awareness of the moment (Mayer, 2000). According to Siegel, Germer and Olendzki'a (2009) it is the process of monitoring inner and outer stimuli without judging them. It's the analysis of the stimuli without judging (Saricam \& Sahin, 2015). It is to become aware of worries through insight ability, and to interact with life actively (Siegel, 2010b). It is the diversion of aquisitions of the past towards instant experience (Ozyesil, Arslan, Kesici \& Deniz, 2011a; Ozyesil, 2011b). It's the positive personal transformation step (Siegel, Germer \& Olendzki, 2009). It could be considered to resemble the concepts of inner view, self-monitoring, insight and awakeness. The ability to regulate attention involves the skills of regulating the instant life. Awareness isn't a production of reflex but thought (Bishop et al., 2004). Mindfulness is an enhanced functional awareness in which attention is directed to the moment with the experience presented by life. Mindfulness contributes to development of self-understanding by fostering the feelings of love, compassion and forgiveness as components of self-understanding (Ozyesil, 2011b; Sakız \& Sarıçam, 2015). The state of identification, where self is lost, decreases 
mindfulness. Mindfulness provides an individual with the chance of experiencing negative, positive or neutral life by offering solutions for his/her problems (Germer, 2009) Attention, observation and questioning could offer conscious living opportunity (Kabat-Zinn, 1994). To be influenced by incentives harms mindfulness as it causes automatic reactions (Germer, 2009). The absence of mindfulness is mindlessness. Not to admit or not to mind feeling and thought is to be insensitive (Brown \& Ryan, 2003). Avoidance and over-confrontation is a dimmer of mindfulness (Hayes \& Feldman, 2004). Individual's forming new charts by judging former life as good or wicked could cause decrease in coping functions and increase in psychological problems (Brown, Ryan, \& Creswell, 2007). Mindfulness is the concentration of the distracted mind by disposing distracter judgements. Awareness could be gained by living the moment (Chambers, Gullone, \& Allen, 2009). Concentrating on the moment in an acquiescent manner without refusing and judging brings forth energy, enthusiasm and awareness (Germer, 2009). According to Kabatt-Zinn (2009) basic attitudes in mindfulness are; not to judge, to be patient, to perceive as if it was the first confrontation with the situation, to rely on self existence by taking the responsibility of being self, to be happy without becoming furious, to comply with the instant life without judging and disclaming, to let thoughts that judge the life slide. One of the determiners of being psychologically well is mindfulness (Brown \& Ryan, 2003; Germer, 2005; Kabat \& Zinn, 2009; Lykins \& Baer, 2009). Stress reducing programme increases mindfulness and being psychologically well, and reduces stress (Carmody $\&$ Baer, 2008). The findings that show activities increasing mindfulness enhance individual's subjective, emotional, mental wellbeing, and also social activity level and life quality, have been reached (Colle, Vincent, Cha, Loehrer, Bauer \& Roedler, 2010; Sarıçam, 2015). Mindfulness develops self-regulation strategy (Siegel, 2010a). Elasticising the relation between thought and emotion contributes to release problems. As psychological problems are released, negative effects fade away, and endurance rises (Ogel, 2009).

In association with these explanations, in both school guidance activities and psychological counseling activities bibliotherapy is one of supportive practices. It shortens the period of psychological attainments but enhances their effects. Materialising of this effect and determining whether its sustainability goes on, has become a necessity. To actualise this target biblio group counseling was planned based on the bibliotherapeutic constituents of the story called The Little Prince. To examine the effect of the practice of biblio group counseling is the aim of the research. The basic hypothesis of the study is; "The mindfulness levels of the subjects. who are participating in the Biblio Group Counseling practice Supported with the Story of The Little Prince, are going to rise much more than the subjects' of the control group, and this rise is going to continue two months after the practices are over." The sub hypotheses of the study are;

$\mathrm{H}_{\mathrm{a}}$ : Biblio Group counseling practice students' pretest score averages of mindfulness are going to be significantly higher than the averages of post-test scores.

$\mathrm{H}_{\mathrm{b}}$ : Biblio Group counseling practice students' pretest score averages of mindfulness are going to be significantly higher than the averages of monitoring-test scores.

$\mathrm{H}_{\mathrm{c}}$ : Biblio Group counseling practice students' posttest score averages of mindfulness are not going to be significantly different the averages of monitoring -test scores.

$\mathrm{H}_{\mathrm{d}}$ : Mindfulness posttest score averages of the students participating in Biblio Group Counseling practice are going to be significantly higher than the averages of posttest scores of the control group students.

$\mathrm{H}_{\mathrm{e}}$ : Mindfulness monitoring-test score averages of the students participating in Biblio Group Counseling practice are going to be significantly higher than the averages of posttest scores of the students of control group.

$\mathrm{H}_{\mathrm{e}}$ : Mindfulness pretest, posttest and monitoring-test score averages of the control group students are not going to be significantly different from each other.

\section{Method}

The pattern of the present research is an experimental study analysing the impact of Biblio Group Counseling Supported with The Story of The Little Prince on the levels of mindfulness. The independent variable of the study is Biblio Group Counseling Supported with the Story of The Little Prince; the dependent variable is the students' mindfulness levels obtained from the scores of Mindful Attention Awareness Scale (MAAS).

The present study is carried out with an experimental group and a control group consisting of university students. Developed by the researcher, Biblio Group Counseling Supported with the Story of The Little Prince was applied to the experimental group, and no operation was held with the control group. In the present study, experimental pattern with experimental and control groups, pretest, posttest and monitoring test measurements was used. The pattern of the research is $2 \times 3$ split-plot pattern. Based on this pattern, as the pretest, mindfulness scales were applied to the students taking place in experimental and control groups two weeks before the beginning of the sessions. Two weeks after this practice, Biblio Group Counseling Supported with the Story of The Little Prince, which was developed by the 
researcher, was applied to the experimental group. During this process no operation was held with the control group. Two weeks after the sessions were completed, as posttest, scales were applied to experimental and control groups. With the purpose of testing whether the effect of Biblio Group Counseling Supported with the Story of The Little Prince is time independent and long lasting, in an effort to find out its permanence, the same scale -as monitoring test- was reapplied to the two groups two months after the posttests were carried out. The experimental pattern of this study is shown in Table 1.

Table 1. Stages of the Experimental Study

\begin{tabular}{lllll}
\hline & & & \multicolumn{2}{c}{ MEASUREMENTS } \\
\hline GROUPS & Pretest & Application & Posttest & Monitoring \\
Experiment & MAAS & Biblio Group Counseling Supported with the Story of & MAAS & MAAS \\
Tontrol & MAAS & - & MAAS Little Prince & MAAS \\
\hline
\end{tabular}

The study group of the research consists of 20 university students studying at Bülent Ecevit University in the spring term of 2015-2016 education years. The practices of the scales were carried out by the group leaders. In the research totally 20 students, 10 females and 10 males, took part within experimental and control groups.

\subsection{Data Collecting Tools}

Data collecting tools utilized in this research are; personal information form with personal and demographic information written on which is used for forming experimental and control groups, and Mindful Attention Awareness Scale (MAAS) which was developed by Brown and Ryan (2003), is a single factored scale measuring individual's awareness level. Internal consistency coefficient of the scale is .82. MAAS was adopted into Turkish by Ozyesil, Arslan, Kesici and Deniz (2011a). The scale shows one dimensional structure with respect to the results of exploratory and confirmatory factor analyses. In item total corelation which was carried out for MAAS, relation was concluded in .40 and over for all the items of the scale. Item factor loads range between .48 and .81 for each item of MAAS Scale. Cronbach Alpha internal consistency coefficient of the scale was found .80 , and test-retest corelation was found .86 .

\subsection{Data Collection Procedure}

This research was carried out with the study group consisting of Bülent Ecevit University Ereğli Faculty of Education students studying in the spring term of 2015-2016 education years. With the aim of determining the students that would participate in experimental and control groups, personal information form and MAAS were applied to 240 active students by the researcher. The research was conducted with experimental and control groups consisting of university students. Biblio Group Counseling Supported with the Story of The Little Prince was applied to experimental group in 6 sessions.

The most important criterion in forming experimental and control groups was individuals' scores of MAAS. Students were lined in terms of the scores taken in the scale. 50 students with lower scores were invited to the study. In the process of determining experimental and control groups' 20 students, volunteering for participating in the sessions of Biblio Group Counseling Supported with the Story of The Little Prince, were randomly appointed to two groups by lot. Two groups were determined as experimental group and control group by lot method.

\subsection{Experimental Tasks}

In this research Biblio Group Counseling Supported with the Story of The Little Prince was applied to the individuals forming experimental group in 6 sessions each of which takes nearly 50 to 60 minutes. The sessions were organized as single session per week. All the sessions were carried out with the leadership of the researcher in Bülent Ecevit University Ereğli Faculty of Education. Group members approved voice recording in the first session.

The programme of Biblio Group Counseling Supported with the Story of The Little Prince; was developed by utilizing the book of The Little Prince by Saint-Exupery (2015) and the essays of Oner (1987), Jackson and Nelson (2002), Forgan (2002), Oner and Yesilyaprak (2006), Oner, (2007), Bulut (2010a;b), Oncu, (2012). The group leaders consulted for views of three expert academicians for book selection. These experts approved the utility of The Little Prince story and Biblio Group Counseling programme for enhancing the levels of mindfulness. The sessions of Biblio Group Counseling Supported with the Story of The Little Prince;

Session 1: Development of therapeutic relation based on confidence was aimed. In this session, structuring the counseling process and developing relations among the members based on confidence were given importance. Additionally, the subjects of introduction, group rules (confidentiality, attendance, and assignments), the process of reading the story book of The Little Prince, taking written notes and recording of sessions were determined. Besides, volunteering contracts were signed by the group members deciding to participate in the study voluntarily. 
Session 2: Finding out the situations forming identification and reflection was aimed. In this session, exploring the situations in which the counselees find an opportunity to reflect their own feelings and identification they made with the protogonist is focused on. Individuals' identification cases are underlined by dynamic analysis which are held in terms of the protogonist of the book and the network of relations.

Session 3: The aim of analysing the cases that form refinement and relief. In this session the feelings of the counselee suppressed are revealed. By setting relationship with their own lives, opportunities of living refinement and relief are provided for the counselees. The cases forming refinement and relief in the story of The Little Prince are focused on.

Session 4: In this session the skills of mindfulness and insight are concentrated on. Mindfulness actualising in the counselees is defined. The analyses of change processes formed by mindfulness and insight in the counselees are carried out. Settlement of insight and mindfulness, which was developed with emotional relief brought by the counselee's refinement and relief, is focused on.

Session 5: In this session, watching and analysing the film of The Little Prince take place. The counselees are suggested to pay attention to the cases forming identification, reflecting their feelings, providing mindfulness and insight, bringing relief during watching the film. The counselees are informed that their acquisitions are going to be held in the following session.

Session 6: It's the stage of integration. The factors, which would provide therapeutic transformation with the help of the counselor, are summarized. The qualifications in The Little Prince Certificate, properties of The Little Prince that the counselees expressed in the previous sessions are read aloud and used for summarisation. The sessions are finished by the integration of transformation case formed in the counselees in terms of the counselees.

\subsection{Analysis of Data}

With the aim of determining which statistical analyses are to be used in the process of data analysis; it's decided whether parametric or non-parametric tests could be used in the research in association with the results obtained from the homogeneity and normality tests that are held with regard to the pretest measurements. In the research $2 \times 3$ two factor ANOVA technique, which is suitable for the split-plot pattern, could be used for repeated measurements (Field, 2009). In terms of the conclusions of this analysis, when significant difference is seen, with the aim of finding out the source of the difference Benforoni test was carried out as one of multiple comparisons tests. For the analysis of data SPPS 20.00 packed programme was used.

\section{Results}

Pre analyses and their conclusions are to be focused on firstly. Variances need to be homogeneous and data need to be suitable for normal distribution in order to use parametric tests in the research. With the aim of determining whether these conditions are present, findings relating to homogeneity of variances were given in Table 2.

Table 2. MAAS Levene's Homogeneity Test relating to Pre-test Scores

\begin{tabular}{lllll}
\hline Variable & Levene's Statistic & sd1 & sd 2 & $p$ \\
\hline Pre-test & .518 & 1 & 18 & .481 \\
\hline$p>.05$ & & &
\end{tabular}

$p>.05$

As seen in Table 2 the result obtained from the homogeneity test, which was done on account of pretest measurements with MAAS, was found as $(\mathrm{F} 1-18=, 518, \mathrm{p}>.05)$. It can be said that there isn't a significant difference between the averages of scores that individuals of the two groups got in the measurements in MAAS, and this fits the basic hypothesis of parametric tests by showing homogeneous distribution. In the cases in which the number of $\mathrm{n}$ in data set is 30 and below thirty Shapiro-Wilks test is used for the analysis of normality values (Field, 2005; Akbulut, 2011; Buyukozturk, 2011). The results of Shapiro-Wilks test are demostrated in Table 3.

Table 3. MAAS Shapiro-Wilks Normality Test Results of Pre-test Scores

\begin{tabular}{llll}
\hline Groups & Statistic & sd & $p$ \\
\hline Experimental & .94 & 10 & .51 \\
Control & .93 & 10 & .69 \\
\hline$p>.05$ & & &
\end{tabular}

According to the results of Shapiro-Wilks Normality Test shown in Table 3, it's seen that data is suitable for the distribution values. It was decided to use parametric analysis techniques to compare the scores of experimental and control groups.

In the process of the research, at the beginning of empirical treatment t-test was carried out for independent samples in order to find out whether there was a significant difference between experimental and control groups, and the results are shown in Table 4. 
Table 4. MAAS Independent Sample t-test Analysis Results of Pre-test Scores

\begin{tabular}{llllll}
\hline & $\mathrm{N}$ & $\bar{X}$ & $\mathrm{~S}$ & $\mathrm{t}$ & $p$ \\
\hline Experimental Group & 10 & 43.6 & 4.50 & -.728 & .476 \\
Control Group & 10 & 42.0 & 5.29 & &
\end{tabular}

It was found out that there wasn't a significant difference between groups as a consequence of analysis $\left(\mathrm{t}_{20}=-.728\right.$, $\mathrm{p}=.476$ ). At the beginning of empirical treatment it was found out that experimental and control groups had homogeneous distribution.

With the aim of testing the basic hypothesis of the research, for repeated measurements over one factor, two factor variance analysis (ANOVA) was used to find out whether there are significant difference between the averages of the mindfulness scores that individuals of experimental and control groups obtained in MAAS scale pretest, posttest and monitoring test measurements. The results are shown in Table 5.

Table 5. Two Factor Variance Analysis Results Related to MAAS Pretest, Posttest and Monitoring Test Scores of Experimental and Control Groups

\begin{tabular}{lcccccc}
\hline Source & $\begin{array}{l}\text { Squares } \\
\text { Total }\end{array}$ & sd & $\begin{array}{l}\text { Squares } \\
\text { Average }\end{array}$ & F & $p$ & $\begin{array}{l}\text { Eta } \\
\text { Square }\end{array}$ \\
\hline Between Groups & & & & & & \\
Groups(Experiment-Control) & 212.82 & 1 & 212.82 & $3.03^{*}$ & .00 & .14 \\
$\begin{array}{l}\text { Error } \\
\text { In Groups (Subjects) }\end{array}$ & 1265.37 & 18 & 70.30 & & & \\
Measurement(Pre-Post-Monitoring) & 35.83 & 1 & 17.92 & $10.94^{*}$ & .00 & .38 \\
Group*Measurement & 35.23 & 1 & 17.62 & $10.76^{*}$ & .00 & .37 \\
Error & 58.93 & 18 & 1.64 & & & \\
\hline
\end{tabular}

$* p<.01$

As seen in Table 5 in conclusion of variance analysis based on MAAS pretest, posttest and monitoring test score averages of experimental and control groups, the effect of group was found significant $\left(\mathrm{F}_{(1-18)}=18,61 ; \mathrm{p}<.01\right)$. It can be stated that there is a significant difference between score averages in MAAS of experimental and control groups' pretest, posttest and monitoring test measurements without any distinction.

It is also seen that without group distinction the difference between score averages of individuals' pretest, posttest and monitoring test measurements is significant $(\mathrm{F}(1-18)=10,94 ; \mathrm{p}<.01)$. This finding shows that mindfulness levels of individuals change in accordance with empirical study when group distinction isn't taken into consideration. It's seen that the value, which was obtained from the result of analyzing mutual effect (group*measurement effect), is significant $\left(\mathrm{F}_{(1-18)}=10,76 ; \mathrm{p}<.01\right)$. It's seen that experimental and control group members' mindfulness pretest, posttest and monitoring test measurements changed significantly. When the findings are taken into cosideration, it can be stated that the basic hypothesis of the research was confirmed. The change that was found during measurements relating to mindfulness can be explained with empirical study effect. The findings obtained from variance analysis demonstrate that there is significant difference between groups.

Table 6. Results of Benferonni Multiple Comparisons Test Related to Groups and Measurements

\begin{tabular}{|c|c|c|c|c|c|c|c|}
\hline \multirow[b]{2}{*}{ 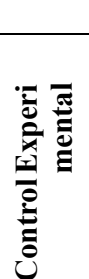 } & & \multicolumn{3}{|c|}{ Experimental Group } & \multicolumn{3}{|c|}{ Control Group } \\
\hline & $\begin{array}{l}\text { Pre-test } \\
\text { Post-test } \\
\text { Monitoring } \\
\text { Pre-test } \\
\text { Post-test } \\
\text { Monitoring }\end{array}$ & $\begin{array}{l}\text { Pre-test } \\
-\end{array}$ & $\begin{array}{l}\text { Post-test } \\
-3.40^{*} \\
-\end{array}$ & $\begin{array}{l}\text { Monitoring } \\
-3.10^{*} \\
.30 \\
-\end{array}$ & $\begin{array}{l}\text { Pre-test } \\
-3.10^{*} \\
5.00^{*} \\
4.70^{*} \\
-\end{array}$ & $\begin{array}{l}\text { Post-test } \\
1.50 \\
4.90^{*} \\
4.60^{*} \\
-.10 \\
-\end{array}$ & $\begin{array}{l}\text { Monitoring } \\
1.70 \\
5.10^{*} \\
4.80^{*} \\
10 \\
.20 \\
- \\
\end{array}$ \\
\hline
\end{tabular}

When the results of Benferonni Test demonstrated in Table 6 are examined, it's seen that pretest average of MAAS ( $\bar{X}$ $=43,60)$, is significantly higher than posttest average $(\bar{X}=47,00)$ and monitoring test average $(\bar{X}=46,70)$ In terms of these results it can be stated that $\mathrm{H}_{\mathrm{a}}$ ve $\mathrm{H}_{\mathrm{b}}$ sub hypotheses of the research were confirmed. There isn't significant difference between monitoring test $(X=46,70)$ and posttest $(\bar{X}=47,00)$ of experimental group $(\mathrm{p}>.05)$. When this finding is taken into consideration, it can be stated that $\mathrm{H}_{\mathrm{c}}$ sub hypothesis of the research was confirmed. It is understood that posttest score average $(X=47,00)$ of experimental group is significantly different from and higher than posttest score average $(\bar{X}=42,10)$ of control group. In terms of this result, $\mathrm{H}_{\mathrm{d}}$ as one of sub hypotheses of the research was confirmed. Monitoring test score average $(X=46,70)$ of experimental group is significantly different from 
and higher than monitoring test score average $(\bar{X}=41,90)$ of control group. It can be stated that He sub hypothesis of the research was confirmed. A significant difference between pretest score averages ( $\bar{X}=43,60)$ of experimental group and pretest score averages $(\bar{X}=42,00)$ of control group wasn't detected. It was found that there wasn't significant difference between pretest score averages $(\bar{X}=42,00)$ of control group, posttest score average $(\bar{X}=42,10)$ and monitoring test score average ( $X=41,90)$ of the same group. With regard to this conclusion, it can be stated that Hf sub hypothesis of the research was confirmed. Line chart of the change related to pretest, posttest and monitoring test scores of experimental and control groups is demonstrated in Figure 1.



Figure 1. Line Chart of the Change Related to Pretest, Posttest and Monitoring Test Scores of Experimental and Control Groups

When we examine Figure 1, it's seen that the gren line belonging to control group doesn't demonstrate explicit difference between the measurements of pretest, posttest and monitoring test and follows a horizontal direction. But the blue line belonging to experimental group demonstrates explicit rise from the pretest practice to posttest practice, and monitoring test reveals that this direction goes on. In association with this, it can be stated that the practice of Biblio Group Counseling Supported with the Story of The Little Prince enhanced mindfulness levels and caused a significant impact. It's seen that the lines in the chart aren't parallel to each other or cyclical. It can be expressed that F value belonging to mutual effect that was found as a result of Variance Analysis reflects significant differences.

\section{Conclusion}

When a general inference was made with regard to the findings of the research, it can be stated that Biblio Group Counseling Supported with the Story of The Little Prince enhanced mindfulness levels of individuals in experimental group, this rise is persistent, this result stems from the effect of empirical practice, and sub hypotheses were confirmed. In conclusion, it was found out that Biblio Group Counseling Supported with the Story of The Little Prince was influential in rising mindfulness levels in the research. Conclusions relating to the basic hypothesis of the research are lined below:

a) A significant difference was found between pretest, posttest and monitoring test measurements of experimental and control groups in MAAS.

b) The difference between score averages that individuals obtained from pretest, posttest and monitoring test measurements is significant without group distinction. Namely, when group distinction isn't made, mindfulness levels of individuals change with the impact of empirical work.

c) As a result of analysing mutual effect (group*measurement effect) the value obtained is significant. The averages of scores which experimental and control group individuals obtained from measurements in mindfulness pretest, posttest and monitoring test, change.

In order to analyse sub hypothesis of the research, mindfulness levels of experimental and control groups were compared inter-group and inter-measurements in association with pretest, posttest and monitoring test measurements. As a result of comparisons 6 sub hypotheses were confirmed. It was found out that the difference between groups can be explained with empirical work effect.

\section{Discussion}

Many activities such as reading the story of the Little Prince, discussing, watching the film of the Little Prince, adding episodes to the story of the Little Prince were carried out in counseling with group sessions. Biblio Counseling practice took 6 sessions. During these sessions, group members expressed "Oracular and strong expression of the story is hope enhancing. Happiness is perception. Change of perception could change the level of happiness. Owning objects 
shouldn't be seen as a tool of being happy. Targets of happiness shouldn't be left to far plans, but they should be actualised by living the moment. Innocency and purity of childhood is purifying. Childish purity and innocency of The Little Prince provides life with sources of power that we need such as energy, change, desire and hope. It gives opportunity of realising of imagination which unlocks life. The individual who has this imagination gets the flexibility of adapting to new situations. Efforts should be made in order not to lose purity, innocence and imagination under the pressure of adult life. The responsibilities which aren't carried out should be cared for as much as the ones which are fulfilled. Feeling of owning is the dimmer of the sensations like love, respect, freedom and happiness. Feeling of to be is developer. Love gets meaning, becomes strong, rises and takes roots by spending effort. The aim of life is action. Love increases if it is presented without self-seeking and condition. The thing that makes the one you loved unique and sole is the connection strengthening with the effort you performed. In order to make love take root you need to explore and identify the love language of the one you loved. The core of the reality isn't seen. Human can see the core of life when he looksby heart. Adding heart is to know the one you loved, not to forget and strengthen the connection. When one looks for by heart, a person can easily find the thing or the one he looked for. Friendship is a need for all the people. The people whom The Little Prince comes across with in his inter-planets travels are looking for friend and are lonely. A person should look by heart, love and make efforts with self abnegation and patience to make friend. To consider making friend is easy misleads a person." It's understood in relation with these expressions that experience of the group contributed to arouse awareness during the process. Additionally, it was stated in the sessions that group experience had supported the development of mindfulness of the group members.

The findings of the research demonstrate that the reason of the rise in the levels of mindfulness of the group members is Biblio Group Counseling Supported with the Story of The Little Prince. In the literature there are many studies coherent with this finding. In the studies of Watson (1980), Pardeck and Pardeck (1984), Oner (1987), Jackson \& Nelson (2002), Forgan (2002), Oner and Yesilyaprak (2006), Oner, (2007), Bulut (2010a;b), (Oncu, 2012) it was repeated that mindfulness gained with the practices of Bibliotherapy could contribute to individuals' psychological health. Janavičiene (2010) in the study emphasizes that bibliotherapy can be used for providing with emotional support, experiencing a feeling or thought and gaining motivation to develop awareness and personality. Preter, Dyches and Johnstun (2006) stated that developing awareness can actualise understanding and compliance. According to Campell and Smith (2003) bibliotherapy contributes to develop cognitive awareness in the process of developing insight. Ivey, Ivey and Downing (1987) suggest that the process of developing awareness relating to the skill of recognizing the truth should be pursued in group environment accompanied with counselor. Another reason of the effectiveness of this research can be explained with little group counseling quality. According to Dowing (2007) successful practices can be obtained individually or in little counseling groups in the process of psychological counseling practice.

It was found out in the monitoring tests that the permanance effect of the rise in mindfulness levels had continued. According to Van Lankveld (1998) the effectiveness of bibliotherapy acquisitions is short term. This research has conclusions in contrast with this finding. According to Kohutek (1983), Scogin, Jamison and Davis (1990) and Ackerson, Scogin, McKendree-Smith and Lyman (1998) permanence of the acquisitions of bibliotherapy is long term. The finding relating to the permanence effect in this researech is consistent. Kohutek (1983) explains the permanence effect's being long term with the fact that bibliotherapy supported with interactive conversation effects self image positively and improves emotion control skills. It can be considered that interaction presented by methods and techniques of psychological counseling with group is available in this research. Gould ve Clum (1993) and Gellatly, Bower, Hennessy, Richards, Gilbody and Lovell (2007) emphasize that the support of counselor is the factor that enhances the success in bibliotherapy. Bibliotherapy can provide contribution to curative role of counselor (Gladding \& Gladding, 1991; Campbell \& Smith, 2003). In this research psychological counseling with group was performed by utilizing bibliotherapeutic constituents of The Little Prince story with leadership of the counselor. That the practice process of the research has the qualities defined in literature could have rised mindfulness level. In many studies such as Bowman, Scogin and Lyrene (1995), Ackerson, Scogin, Mc Kendree-Smith and Lyman (1998), Lander ville, Landry, Baillargeon, Guerette and Matteau (2001), Tolin (2001), Prater, Dyches and Johnstun (2006), Jones (2006), Oner (2007) it is emphasized that bibliotherapy supports individual psychologically beside its clinical benefits. Individual actualises his/her treatment by the way of reading in the process of psychological counseling (Bulut, 2010a). This process is a kind of process which transforms into acquisition of insight (Oncu, 2012). There is a prevalent consideration on account of effectiveness of bibliotherapies (Oner and Yesilyaprak, 2006). In this research the way of utilizing treatment through reading was preferred. This case supports the effectiveness of this research with the contribution it provided for insight acquisition as it was stated previously. The other reason of effectiveness of this research can be related with the fact that biblio group counseling was carried out with individuals whose education levels were high. In the studies of Scogin, Jamison and Goehneaur (1989) and Bulut (2010a) it is emphasized that the effectiveness of bibliotherapy increases in relation with the rise in counselees' education levels. In addition to this, Pardeck (1994) emphasizes that bibliotherapy can initiate the change that will develop individuals with no troubles in addition to the fact that it can offer support for 
troubled individuals of all ages. Additionally, McKendree-Smith, Floyd and Scogin (2003) and Pardeck and Pardeck (1984), Bulut (2010b) consider bibliotherapy as one of the most influential methods of preventive guidance services. It is the preventer of problematic behavior or facilitator of solutions for problems. When considered from this point of view, it can be supposed that in terms of the finding revealing the permanence effect of mindfulness continues, mindfulness skills obtained in this research can transform into preventive qualities.

That the research was supported with The Little Prince story and pursued benefiting from methods and techniques of counseling with group could be other reasons of its effectiveness. This conclusion matches up with the finding of Jones (2006).

Some suggestions can be presented in the context of the conclusions come up with in the research. This research was applied to individuals of early adulthood. It can be suggested that this research could be applied to individuals of adolescence period with experimental studies. Sharing the details of session of Biblio group guidance used in researches or of the programmes used in group counseling by the help of books or documents could contribute to disseminative effect. There is a need for bibliotherapy to be popularised considering its preventive quality. Therefore some platforms, in which psychological counseling experts with experience of bibliotherapy can share their experience, should be formed. Additionally, collecting the books with bibliotherapeutic quality in bibliotherapy data base and making them accessible to users could contribute to researchers and the counselees who want to develop themselves.

\section{References}

Ackerson, J., Scogin, F., McKendree-Smith, N., \& Lyman, R. D. (1998). Cognitive bibliotherapy for mild and moderate adolescent depressive symptomatology. Journal of Consulting and Clinical Psychology, 66(4), 685-690. http://dx.doi.org/10.1037/0022-006X.66.4.685

Bishop, S. R., Lau, M., Shapiro, S., Carlson, L., Anderson, N. D., Carmody, J., Segal, Z. V., Abbey, S., Speca, M., Velting, D., \& Devins, G. (2004). Mindfulness: A proposed operational definition. Clinical Psychology: Science and Practice. 11, 230-241. http://dx.doi.org/10.1093/clipsy.bph077

Bowman, D., Scogin, F., \& Lyrene, B. (1995). The efficacy of self-examination therapy and cognitive bibliotherapy in the treatment of mild to moderate depression. Psychotherapy Research, 5(2), 131-140.

Brown, K. W., \& Ryan, R. M. (2003). The benefits of being present: Mindfulness and its role in psychological well-being. Journal of Personality and Social Psychology, 84, 822-848. http://dx.doi.org/10.1037/0022-3514.84.4.822_

Brown, K., Ryan, R., \& Creswell, J. (2007). Mindfulness: Theoretical foundations and evidence for its salutary effects. Psychological Inquiry, 18(4), 211-237. http://dx.doi.org/10.1080/10478400701598298

Bulut, S. (2010a). Application of bibliotheraphy methods by school counselor and teachers in school setting. Electronic Journal of Social Sclences, 34(34).

Bulut, S. (2010b). Using bibliotheraphy in adult counseling. Turkish Psychological Counseling and Guidance Journal 4(33), 46-56.

Campbell, L. F., \& Smith, T. P. (2003). Integrating selfhelp books into psychotherapy. Journal of Clinical Psychology/In Session, 59(2), 177-186. http://dx.doi.org/10.1002/jclp.10140

Carmody, J., \& Baer, R. A. (2008). Relationships between mindfulness practice and levels of mindfulness, medical and psychological symptoms and well being in a mindfulness-based stress reduction program. Journal of behavioral medicine, 31(1), 23-33. http://dx.doi.org/10.1007/s10865-007-9130-7

Chambers, R., Gullone, E., \& Allen, N. A. (2009). Mindful emotion regulation: An integrative review. ClinicalPsychology Review, 29, 560-572. http://dx.doi.org/10.1016/j.cpr.2009.06.005

Colle, F. K. F., Vincent, A., Cha, S. S., Loehrer, L. L., Bauer, B. A., \& Wahner-Roedler, D. L. (2010). Measurement of quality of life and participant experience with the mindfulness-based stress reduction program. Complementary Therapies in Clinical Practice, 16(1), 36-40. http://dx.doi.org/10.1016/j.ctcp.2009.06.008

de Saint-Exupéry, A. (2013). Küçük Prens. Istanbul: Can.

Downing, J. A. (2007). Students with emotional and behavioral problems: Assessment, management, and intervention strategies. Prentice Hall.

Field, A. (2009). Discovering statistics using SPSS. Sage publications.

Forgan, J. W. (2002). Using bibliotherapy to teach problem solving. Intervention in School and Clinic, 38, 75-82. http://dx.doi.org/10.1177/10534512020380020201

Gellatly, J., Bower, P., Hennessy, S., Richards, D., Gilbody, S., \& Lovell, K. (2007). What makes self- help interventions effective in the management of depressive symptoms? Meta-analysis and meta-regression. Psychological Medicine, 37, 1217-1228. http://dx.doi.org/10.1017/S0033291707000062 
Germer, C. (2005). Mindfulness: What is it? What does it matter? In C. K. Germer, R. D. Siegel, \& P. R. Fulton (Eds.), Mindfulness and psychotherapy (pp. 3-27). New York, NY: Guilford Press.

Germer, C. K. (2009). The mindfulpath to self-compassion: Freeing yourself from destructive thoughts and emotions. Hove: Routledge.

Germer, C. K., Siegel, R. D., \& Fulton, P. R. (2005). Mindfulness and psychotherapy. New York: Guilford.

Gilbert, P. (2005). Compassion and cruelty: A biopsychosocial approach. In P. Gilbert (Ed.), Compassion: Conceptualisations, research and use in psycho Nyanaponika Therapy (pp. 9-74). Hove: Routledge.

Gladding, S. T., \& Gladding, C. (1991). The ABCs of bibliotheraphy for school counselors. School Counselor, 39(1), 7-12.

Gould, R. A., Clum, G. A., \& Shapiro, D. (1993). The use of bibliotherapy in the treatment of panic: A preliminary investigation. Behavior Therapy, 24(2), 241-252. http://dx.doi.org/10.1016/S0005-7894(05)80266-7

Gregory, R. J., Canning, S. S., Lee, T. W., \& Wise, J. C. (2004). Cognitive Bibliotherapy for Depression: A Meta-Analysis. Professional Psychology Research and Practice, (35)3, 275-280. http://dx.doi.org/10.1037/0735-7028.35.3.275

Hayes, A. M., \& Feldman, G. (2004). Clarifying the construct of mindfulness in the context of emotion regulation and the process of change in therapy. Clinical Psychology Science and Practice, 11, 255-262. http://dx.doi.org/10.1093/clipsy.bph080

Ivey, A. E., \& Ivey, M. B., \& Downing, L. S. (1987) Counseling and Psychotherapy. Interpreting Skills, Theory and Practice. New Jersey: Prentice-Hall International,Inc..

Jackson, S. A., \& K. W. Nelson. (2002). Use of children's literature in a comprehensive school guidence program for young children. Early Childhood Literacy. Texas:Yearbook.

Janavičiene, D. (2010). Bibliotherapy process and type analysis: Review of possibilities to use it in thelibrary. Tiltai. Klaipeda University, (Lithuanian), 4(53), 119-132.

Jones, J. L. (2006). A closer look at bibliotherapy. (pp.24-27).Young Adult Libraiy Services Fall.

Kabat-Zinn, J. (1994). Wherever you go there you are. New York: Hyperion.

Kabat-Zinn, J. (2009). Full catastrophe living: Using the wisdom of your mind and body to face stress, pain, and illness. New York: Delacorte.

Karaırmak, O. (2015). Çocukla psikolojik danışmada metaforik süreç. Türk Psikolojik Danışma ve Rehberlik Dergisi, $5(43)$.

Kohutek, K. J. (1983). Bibliotherapy within a correctional setting. Journal of Clinical Psychology, 39, 920- 924.

Lakoff, G., \& Johnson, M. (2003). Metaphors we live by. Chicago: The University of Chicago Press.

Landreville, P., Landry, J., Baillargeon, L., Guerette, A., \& Matteau, E. (2001). Older adults' acceptance of psychological and pharmacological treatments for depression. The Journals of Gerontology, 56B, 285-291. http://dx.doi.org/10.1093/geronb/56.5.P285

Laquinta, A., \& Hipsky, S. (2006). Practical bibliotherapy strategies fort the inclusive elementary classroom. Early Childhood Education Journal, 34(3). http://dx.doi.org/10.1007/s10643-006-0128-5

Lykins, E. L. B., \& Baer Ruth A. (2009). Psychological Functioning in a Sample of Long- Term Practitioners of Mindfulness Meditation: Journal of Cognitive Psycho Nyanaponika Therapy. An International Quarterly, 23, 226-241. http://dx.doi.org/10.1891/0889-8391.23.3.226

Marlowe, M., \& Maycock, G. (2000). Phenomenology of bibliotherapy in modifying teacher punitiveness. The Journal of genetic psychology, 161(3), 325-336. http://dx.doi.org/10.1080/00221320009596715

Mayer, J. (2000). Spiritual intelligence or spiritual consciousness. International Journal for the Psychology of Religion, $10(1), 47-56$.

McCarthy, H., \& Chalmers, L. (1997) Bibliotherapy intervention and prevention. Teaching Exceptional Children, 29, 12-17.

McCulliss, D. (2012). Bibliotherapy: Historical and research perspectives. Journal of Poetry Therapy, 25(1), 23-38.

McKendree-Smith, N. L., Floyd, M., \& Scogin, F. R. (2003). Self-administered treatments for depression: A Review. Journal of Clinical Psychology, 59(3), 275-288. http://dx.doi.org/10.1002/jclp.10129

Mills, J. C., \& Crowley, R. J. (1986). Therapeutic metaphors for children and the child within. New York: Brunner/Mazel.

Ogurlu, Z., \& Sarıcam, H. (2015). Metacognitive awareness and math anxiety in gifted students. Cypriot Journal of Educational Sciences, 10(4), 338-348. http://dx.doi.org/10.18844/cjes.v10i4.151

Oncü, H. (2012). Bibliyoterapi Yönteminin Okullarda Psikolojik Danişma ve Rehberlik Amaciyla Kullanilmasi TSAD 
16(1), 147-170.

Oner, U. (1987). Bibliyoterapi. Ankara University Journal of Faculty of Educational Sciences, 20, 1-2

Oner, U. (2007). Bibliyoterapi. Cankaya University Journal of Arts and Sciences, 7, 133-150.

Oner, U., \& Yeşilyaprak, B. (2006). Bibliyoterapi. Children's and Youth Literature Symposium. (pp. 559-565) Ankara: Ankara University.

Ozyesil, Z. (2011b). Oz-Anlayış ve Bilinçli Farkındalık. Istanbul: Maya

Ozyesil, Z., Arslan, C., Kesici, S., \& Deniz, M. (2011a). Adaptation of the mindful attention awareness scale into Turkish. Education and Science, 36(160), 224-235.

Pardeck, J. T. (1993). Literatüre and adoptive children with disabilities. Early Child Development and Care, 91, 33-39.

Pardeck, J. T., \& Pardeck, J. A. (1984). Young people with problems: A guide to bibliotherapy. Westport, Connecticut: Greenwood Press.

Pardeck, J. T., \& Pardeck, J. A. (1993). Bibliotherapy: A clinical approuch for helping children. New York: Gordon and Breach Science Publishers.

Prater, M. A., \& Dyches, T. T. \& Johnstun, M. (2006). Teaching students about disabilities through children's literature. Intervention in School and Clinic, 4(1), 14-24.

Sakız, H., \& Sarıcam, H. (2015). Self-compassion and forgiveness: The protective approach rejection sensitivity against. International Journal of Human Behavioral Science, 1(2), 10-21.

Sarıcam, H. (2015). Metacognition and happiness: The mediating role of perceived stress. Studia Psychologica, 57(4), 271-283.

Sarıcam, H., \& Sahin, S. H. (2015). The relationship between the environmental awareness, environmental attitude, curiosity and exploration in highly gifted students: Structural Equation Modelling. Educational Process: International Journal, 4(1-2), 7-17. http://dx.doi.org/10.12973/edupij.2015.412.1

Scogin, F., Jamison, C., \& Davis, N. (1990). Two-year follow-up of bibliotherapy for depression in older adults. Journal of Consulting and Clinical Psychology, 58, 665- 667. http://dx.doi.org/10.1037/0022- 006X.58.5.665

Scogin, F., Jamison. C., \& Goehneaur, K. (1989). Comparative efficacy of cognitive and behavioral bibliotherapy for mildly and moderately depressed older adults. Journal of Consulting and Clinical Psychology, 57, 403-407. http://dx.doi.org/10.1037/0022-006X.57.3.403

Siegel, J. D. (2010a). The Mindful Nyanaponika Therapist. New York: W. W. Norton \& Company, Inc.

Siegel, R. D. (2010b). The Mindfulness Solution: Everyday Practices for Everyday Problems. NY: Guilford Press.

Siegel, R. D., Germer, C. K., \& Olendzki, A. D. (2009). Mindfulness: What is it? Where did it come from? F. Didonna (Ed.), Clinical Handbook of Mindfulness. (pp. 17-35). New York: Springer Science

Stahl, B., \& Goldstein, E. (2010). A mindfulness-based stress reduction workbook. Oakland: New Harbinger.

Tolin, D. F. (2001). Case study: Bibliotherapy and extinction treatment of obsessive-compulsive disorder in a 5-year-old boy. Source: Journal of the American Academy of Child and Adolescent Psychiatry, 40(9), 1111-4. http://dx.doi.org/10.1097/00004583-200109000-00021

Turner, J. (2008). Bibliotheraphy for health and wellbeing: An effective investment. Aplis, 21(2), 56-61.

Van Lankveld, J. J. D. M. (1998). Bibliotherapy in the treatment of sexual dysfunctions: A meta-analysis. Journal of Consulting and Clinical Psychology, 66(4), 702-708. http://dx.doi.org/10.1037/0022-006X.66.4.702

Van Parys, H., \& Rober, P. (2013). Micro-analysis of a therapist-generated metaphor referring to the position of a parentifi ed child in the family. Journal of Family Therapy, 35(1), 89-113. http://dx.doi.org/10.1111/j.1467-6427.2011.00551.x

Watson, J. (1980). Bibliotherapy for abused children. School Counselor, 27, 204-208.

Westen, D. (1999). Psychology: Mind, brain, and culture. New York : Wiley.

Williams, C., \& Martinez, R. (2008). Increasing access to CBT: Stepped care and CBT self -help models in practice. Behavioral and Cognitive Psychotherapy, 36, 675-683.

Yesilyaprak, B. (2009). Bibliyoterapi. 10.01.2016. http://www.binnuryesilyaprak.com

\section{$(\mathrm{cc}) \mathrm{EY}$}

This work is licensed under a Creative Commons Attribution 3.0 License. 